Génét. Sél. Evol., 1986, 18 (2), 173-184

\title{
Heritability of a canalized trait : teat number in Iberian pigs
}

\author{
M.A. TORO, María Teresa DOBAO, J. RODRIGÁÑEZ and L. SILIO \\ Departamento de Genética Cuantitativa y Mejora Animal \\ Instituto Nacional de Investigaciones Agrarias, \\ Carretera de La Coruña, Km. 7. 28040 Madrid, Espagne
}

\begin{abstract}
Summary
Teat number is a discontinuous and often canalized trait in populations of domestic swine. This is the case in the Iberian pig where 90 p. 100 of individuals show 10 teats.

The estimation of genetic parameters for this discrete and strongly leptokurtic trait presents difficulties similar to those encountered in dichotomous ones, and several specific methods of estimation have been suggested, generally assuming the existence of an underlying normally distributed random variable.

Heritability estimates of teat number, based on 30271 animals of three strains of Iberian pig, have been obtained both using conventional correlation and regression methods and through 3 specific techniques proposed by RoBERTSON, Gianola and Tallis. These methods allow one to estimate what proportion of the heritability of the assumed underlying variable $\left(h^{2}\right)$ can be accounted for by the heritability estimated in the observed scale $\left(h_{0}^{2}\right)$. The estimated proportion ranged between 0.30 and 0.75 depending on the degree of canalization of the trait in the 3 different populations considered. The use of these specific methods, despite their interest, may present serious difficulties in practical breeding conditions.
\end{abstract}

Key words : Heritability, discrete traits, teat number, canalization, Iberian pig.

\section{Résumé}

Héritabilité d'un caractère canalisé : le nombre de tétines chez le porc Ibérique

Le nombre de tétines est un caractère discret qui est souvent canalisé dans les populations de porcs domestiques. Tel est le cas chez le porc Ibérique où près de $90 \mathrm{p} .100$ de; individus possèdent 10 tétines.

L'estimation de paramètres génétiques pour ce caractère discret et à une forte leptokurtosis pose des problèmes similaires à ceux rencontrés dans l'étude des caractères dichotomiques, pour lesquels ont été proposées plusieurs méthodes d'estimation qui, généralement, supposent l'existence d'une variable aléatoire sous-jacente ayant une distribution normale.

Des estimations de l'héritabilité du nombre de tétines ont été obtenues sur un total de 30271 animaux appartenant à 3 souches de porc Ibérique par des méthodes conventionnelles de corrélation et régression ainsi que par 3 techniques spécifiques proposées par ROBERTSON, 
Gianola et Tallis. Ces méthodes permettent d'estimer le rapport de l'héritabilité estimée sur l'échelle observée $\left(h_{0}^{2}\right)$ à l'héritabilité de la variable sous-jacente $\left(h^{2}\right)$.

L'estimation de ce rapport varie entre 0,30 et 0,75 selon le degré de canalisation du caractère dans les 3 populations considérées. L'utilisation de ces méthodes spécifiques, malgré leur intérêt, peut poser de sérieuses difficultés dans les conditions pratiques d'élevage. Ibérique.

Mots clés : Héritabilité, caractères discrets, nombre de tétines, canalisation, porc

\section{Introduction}

Teat number in pigs is a meristic trait that sometimes presents a distribution with positive kurtosis, i.e. an excess of values close to the mean. This poses methodological problems in the estimation of genetic parameters similar to those of dichotomous traits.

The main objective of the present work is to obtain heritability estimates of teat number in 3 populations of Iberian pig by means of conventional methods of correlation and regression between relatives and also by specific methods of estimation for discrete traits (Dempster \& Lerner, 1950; TAllis, 1962; Gianola, 1979; Gianola \& Norton, 1981).

Conventional methods estimate the heritability of the trait in the measured scale. Other methods assume the existence of an underlying normally distributed random variable which results in a discontinuous distribution of observed phenotypes due to several threshold values. With these methods heritability estimates in the underlying scale can be obtained.

\section{Material and methods}

The data come from the experimental herd of Iberian pig of « El Dehesón del Encinar» (Oropesa, Toledo) whose origin, characteristics and management conditions have been previously described (Odriozola, 1976 ; Dobao et al., 1982 and 1983).

In relation to the present work it must be pointed out that teat number, examined at 21 days of age, is one of the traits routinely recorded from piglets born in the herd. In general, the individuals with a teat number less than 10 have been excluded from breeding. The mating system in the 3 closed strains of the herd has not been designed to optimize the estimation of genetic parameters. As a consequence, the data reflect overlapping of generations, mating between individuals with minimum coancestry coefficient, unequal family sizes and mating structure not totally hierarchical since females have usually been mated with different males during their reproductive life.

Data from 30271 individuals were classified into 6 files (D1, D2, E1, E2, F1 and F2) according to strain Guadyerbas (D), Torbiscal (E) and Gamito (F) and period 
of birth : (1) animals born from 1963 to 1973 and (2) animals born from 1974 to 1979. These 2 periods correspond to changes in the management conditions of the herd (DoBAo et al., 1983) and the approximate number of generations per period, about 5 generations in E2 and 4 in the others, is not excessive in order to obtain estimates of heritability from each one of the files.

Estimates of heritability in the multinomial observable scale were obtained through the following conventional methods :

1) Full-sibs (Htd) and Half-sibs (Hts) intraclass correlation.

2) Regression of offspring on parents : Sire (Hbs), dam (Hbd), mid-parent $(\mathrm{Hbm})$ and sire plus mean of the dams mated with it (Hba).

In addition, among the published specific methods of heritability estimation for discrete traits, those proposed by the following authors were used :

3) Robertson, who derived in an Appendix to a Dempster \& Lerner (1950) paper, a simple relationship by which heritabilities of a dichotomous or binary trait can be transformed from the observable to the underlying scale. More recently, GiaNolA (1979) has generalized the method for those discrete traits with more than 2 classes of phenotypes. This generalized formula is the one used in the present work.

4) Gianola \& Norton (1981), who have optimized the above method using a scale adjustement.

5) TALlis (1962), who has applied maximum likelihood methods to the estimation of correlation between relatives from $p \times q$ contingency tables, where one of the dimensions corresponds to all the possible phenotypic classes of one parent (sire or dam) and the other to the phenotypic classes of the progeny. Contrasting with the other methods, TALLIS' method permits testing of the assumption of a normally distributed underlying variable, this being its main advantage. In the present work, its use has posed the following difficulties : a) the assumption that the data included in each cell of the contingency table come from independent observations is not fulfilled; b) in the presence of selection and different family sizes, sampling of parents, mainly males, cannot be considered random; c) the available computing program constrains the user to group some of the observed classes to operate on $3 \times 3$ contingency tables. The 3 classes considered in each table consist of the following phenotypes : $\leqslant 10,11$ or $\geqslant 12$ teats, except in the file D2 where the grouped classes are $: \leqslant 9,10$ or $\geqslant 11$ teats.

Recently, non-linear methods regarding the analysis of discrete traits and adopting a Bayes-like approach have been developed by several authors (Gianola \& Foulley, 1983 ; Foulley et al., 1983 ; HaRville \& MEE, 1984). Nevertheless, as some of these authors admit, in animal breeding practice, solving the proposed equations poses a formidable numerical problem (Foulley et al., 1983) and, for this reason, these new methods have not been tried on data.

A rough estimate of the realized heritability was obtained using a formula proposed by TURNER \& Young (1969) for overlapping generations, that assigns a generation number to each individual using pedigrees and therefore permits one to consider it as belonging to discrete generations. The examination of data showed that the number of teats has been subjected to a weak selection pressure in the herd. Cumu- 
lative selection differentials in Guadyerbas, Torbiscal and Gamito were $0.13,0.24$ and 0.49 teats during the first period and $0.0005,-0.25$ and 0.31 during the second one. The realized heritability was estimated by regression of generation means on cumulative selection differentials (FALCONER, 1960).

\section{Results and discussion}

\section{A. Distribution of teat numbers}

Differences in teat number between males and females have not been observed. Therefore, sexes are pooled in table 1 showing teat number distribution according to the strains and periods considered, as well as the estimated values of the means, standard deviations, kurtosis and skewness coefficients. Though there are some differences between groups, all of them share the following characteristics :

1) A modal value of 10 teats, similar to that of the Duroc-Jersey breed related to the Iberian pig, and lower than those of other European and American breeds, like Poland China with 12 teats or Large White, Landrace and Minnesota $\mathrm{n}^{\circ} 1$ with 14 teats (HANSET \& CAMERLYNCK, 1974 ; Clayton et al., 1981), and, of course, much lower than the 16-18 teats of some Chinese breeds (ZHANG et al., 1983; Legaul \& Caritez, 1983).

2) A large majority of individuals (57-93 p. 100) shows the modal 10 teats phenotype, resulting in the positive values of the g.. kurtosis coefficient, highly significant in all cases. Clayton et al. (1981) have observed the same fact, although less marked, in Large White and British Landrace pigs : 55 p. 100 of animals show the modal number of 14 teats. These authors mention the surprising lack of previous comments on this peculiarity of the trait.

3) The values of the $g_{1}$ skewness coefficient are also positive and highly significant showing an excess of phenotypes lower than the mean in all populations ; a similar departure from normality has been observed in Duroc-Jersey breed (HANSET \& CAMERLYNCK, 1974).

Teat number in pigs, according to the features of its frequency distribution, may be considered, from a genetic approach, as a trait arising from a process of canalized development, i.e., fitted to produce a definite phenotype with independence of a certain degree of genetic or environmental variation (WADDINGTON, 1957). The idea of genetic canalization, like that of dominance, refers to the existence of constraints in the phenotypic expression of different genetic combinations.

The work of RENDEL (1967), among others, on the scutellar bristles in D. melanogaster, shows that a system of canalization can be modified through selection or because of the effect of mutants with pleiotropic influence on several processes of development. WADDINGTON (1975) suggests that the effectivity of some colour mutants in the decanalization of developmental processes in domestic animals explains why these genes had been incorporated so frequently in the formation of great breeds of livestock during the XIXth century. 


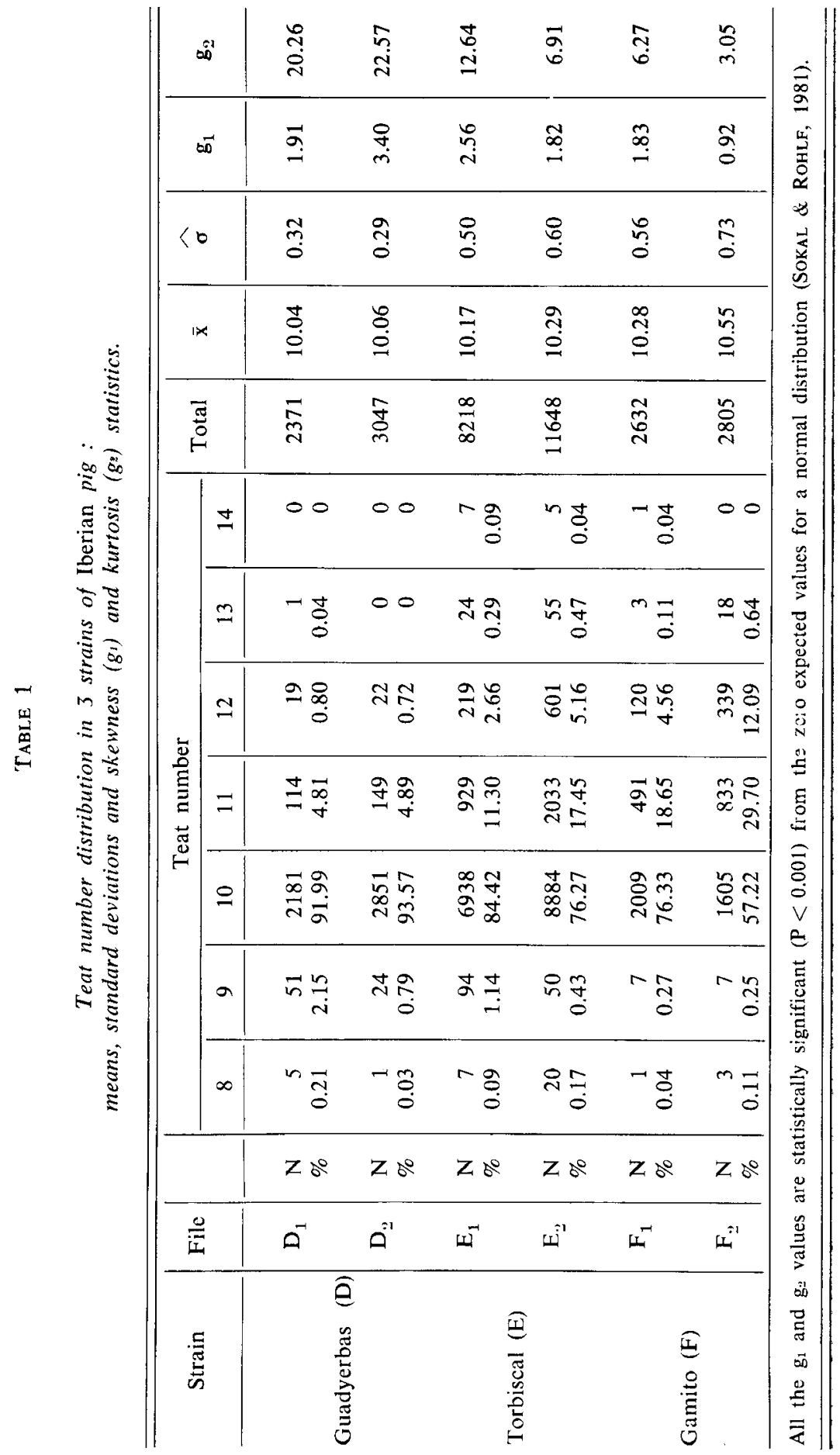


From this point of view the observed differences between strains and between periods in means and $\mathrm{g}_{2}$ values can be interpreted satisfactorily. Strains Guadyerbas and Gamito are particularly interesting. Coming from the same population of black coated pigs, these strains only differed originally in the pair of alleles responsible for coat colour : the wild E allele, black, dominant, fixed in Guadyerbas and the e allele, red, recessive, fixed in Gamito. This pair of alleles has in the Iberian pig, according to ODRIOzola (1976), pleiotropic effects on other traits : body length, age of maturity and teat number. The higher frequency of deviant phenotypes in the strain Gamito has favoured a greater intensity of selection for teat number, increasing the mean value and reducing the degree of canalization of the trait. Analogous differences between periods, ascribable to selection, are also observed in Torbiscal but not in Guadyerbas, where the extreme canalization has not made possible in practice any appreciable selection for this character.

\section{B. Estimates obtained by conventional methods}

Heritability values and their standard errors estimated for the different strains and periods by 6 methods of regression and correlation between relatives are shown in table 2. The irregular structure of the mating system in the herd, mentioned above, requires that these estimates be interpreted cautiously, particularly those obtained by regression on one parent ( $\mathrm{Hbs}$ and $\mathrm{Hbd}$ ), based on less information.

Estimates obtained from the maternal component of variance (Htd) are equal to or greater than those obtained from the paternal one (Hts). Similar results have been consistently recorded by several authors who suggest as an explanation of them a maternal effect on teat number (Hanset \& Camerlynck, 1974 ; Pumfrey et al., 1980 ; Clayron et al., 1981). These authors discard the existence of non-additive genetic variation, as an alternative explanation of the observed differences between estimates, arguing that the literature does not provide clear evidence of heterosis in teat number in pigs. This reasoning is debatable, because the quoted results coming from Landrace $\times$ Large White and Landrace $\times$ Poland China crosses are not consistent, the first showing additivity and the second 4.5 p. 100 of heterosis. These breeds are very distinct both in origin and history; they have different modal values and, presumably, diverse degrees of canalization of the character. According to Falconer (1960), populations that are widely differentiated through adaptations to local conditions may fail to show heterosis and the failure of wide crosses to show the heterosis that might have been expected can be attributed to epistatic interaction. From a molecular approach to dominance, KACSER \& BURNS (1981) have also emphasized that crosses between populations that have diverged from each other by isolation, followed by selection or drift, may show changes in dominance relations. In our opinion, this does not allow one to exclude the possible existence of non-additive genetic variation in teat number in pigs, particularly within those populations or breeds more strongly canalized such as the Iberian pig population.

Estimates of realized heritabilities obtained from all data of Torbiscal and Gamito strains were $0.35 \pm 0.21$ and $0.46 \pm 0.10$ respectively, these values being in agreement with those of table 2 . The extremely low range of variation of cumulative selection differentials in Guadyerbas results in a highly inaccurate estimate ( -0.03 \pm 0.27 ) for this strain. 


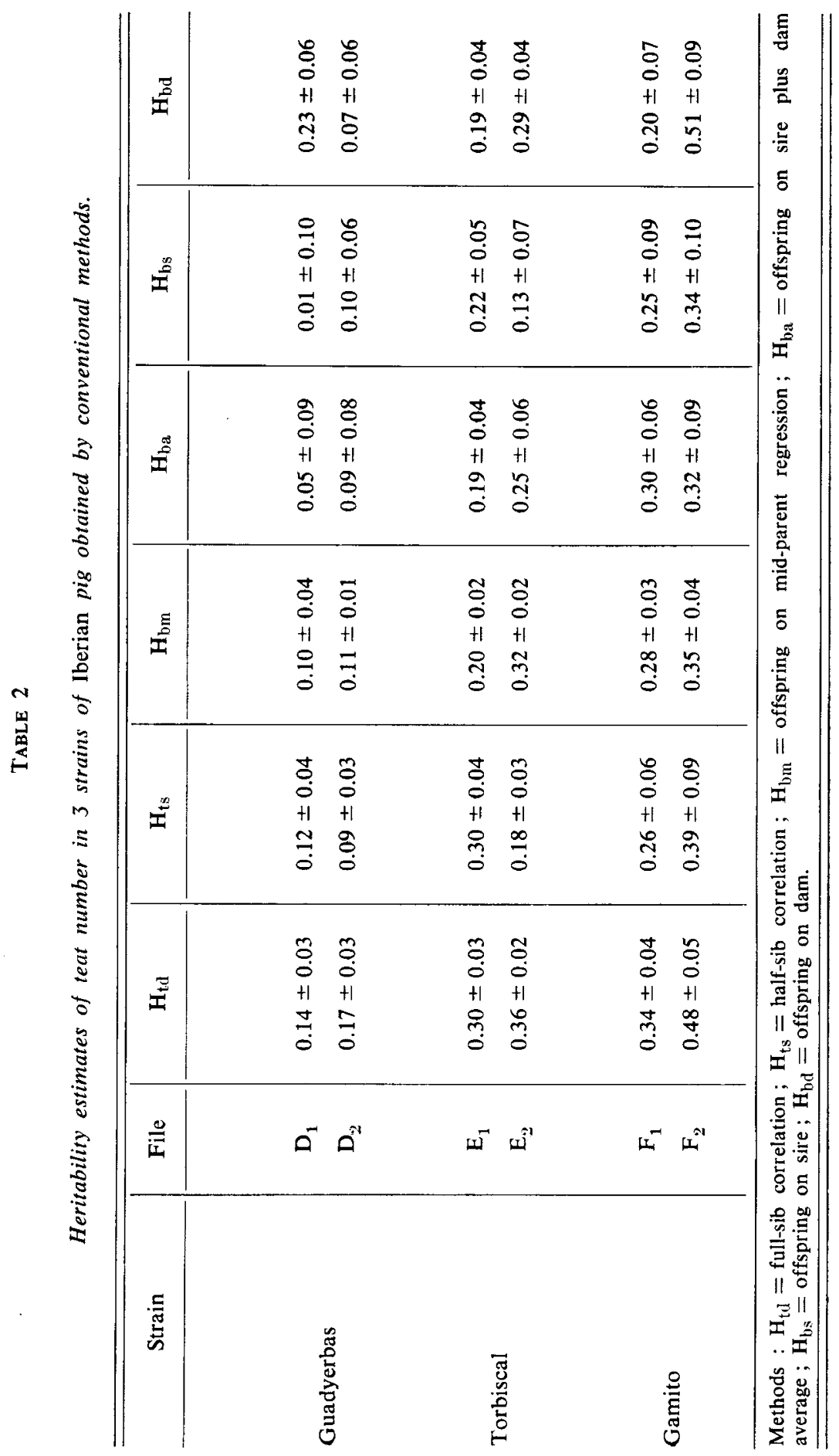




\section{Estimates obtained by specific methods}

The joint examination of tables 1 and 2 suggests that heritability values estimated by conventional methods are associated with the degree of canalization depicted by the distribution of the character in each strain and period. Generally, a greater canalization of the trait corresponds to a smaller estimated value of its heritability.

The objective of using techniques such as those of RoBERTSON \& GianolaNORTON is to consider the effects due to discontinuity and deviations from normality in the estimation of heritability from discrete data. In both methods, an underlying variable with normal distribution is postulated and both allows one to calculate what proportion of the heritability of this variable $\left(h^{2}\right)$ is estimated in the observed scale of phenotypes $\left(\mathbf{h}_{\mathrm{o}}^{2}\right)$.

In the first 2 columns of table 3 results obtained using these methods for the 6 files of data are presented. They confirm that the value of their use is greater as the deviations from normality of the observed discrete trait become larger, and therefore when their degree of canalization is higher. The values of estimates Hts and $\mathrm{Hbm}$ corrected by both methods are also shown in table 3 and evidence a considerable genetic variability in all the strains.

The Gianola-Norton scoring, as the authors indicate, has little advantage over the RoBERTSON method. Its utility is undoubtedly greater for some discrete traits whose scale of possible values is determined through the choice of a subjective classification, as could be conformation scores or degree of calving difficulty.

In table 4 the results of the application of TALLIS' method to the sires/progeny and dams/progeny contingency tables, constructed for different periods and strains, are shown. The $\chi^{2}$ values reflecting the goodness of fit to the model are in general compatible with the assumption of a normal underlying distribution, particularly in dams/progeny contingency tables. Only in one case, the analysis of the sires/progeny table in file $E 1$, is a highly significant value registered.

The estimates obtained confirm that the heritability of the trait is high in the underlying scale, although the values differ sometimes from those obtained by the methods of ROBERTSON \& GIANOLA-NORTON, particularly in the strain Guadyerbas. This implies that increases in teat number can be obtained by means of artificial selection, especially when a less degree of canalization of the character permits higher selection intensities. The use of the heritability of the underlying scale for predicting the response to selection requires the subsequent transformation of the expected response to the observed phenotypic scale. DEMPSTER \& LERNER (1950) showed, for an all-or-none trait, that genetic gains from mass selection will be more accurately predicted, if the assumptions of the threshold model are fulfilled, using the heritability of the underlying scale, particularly for high heritabilities and low incidence levels. 
TEAT NUMBER IN IBERIAN PIGS

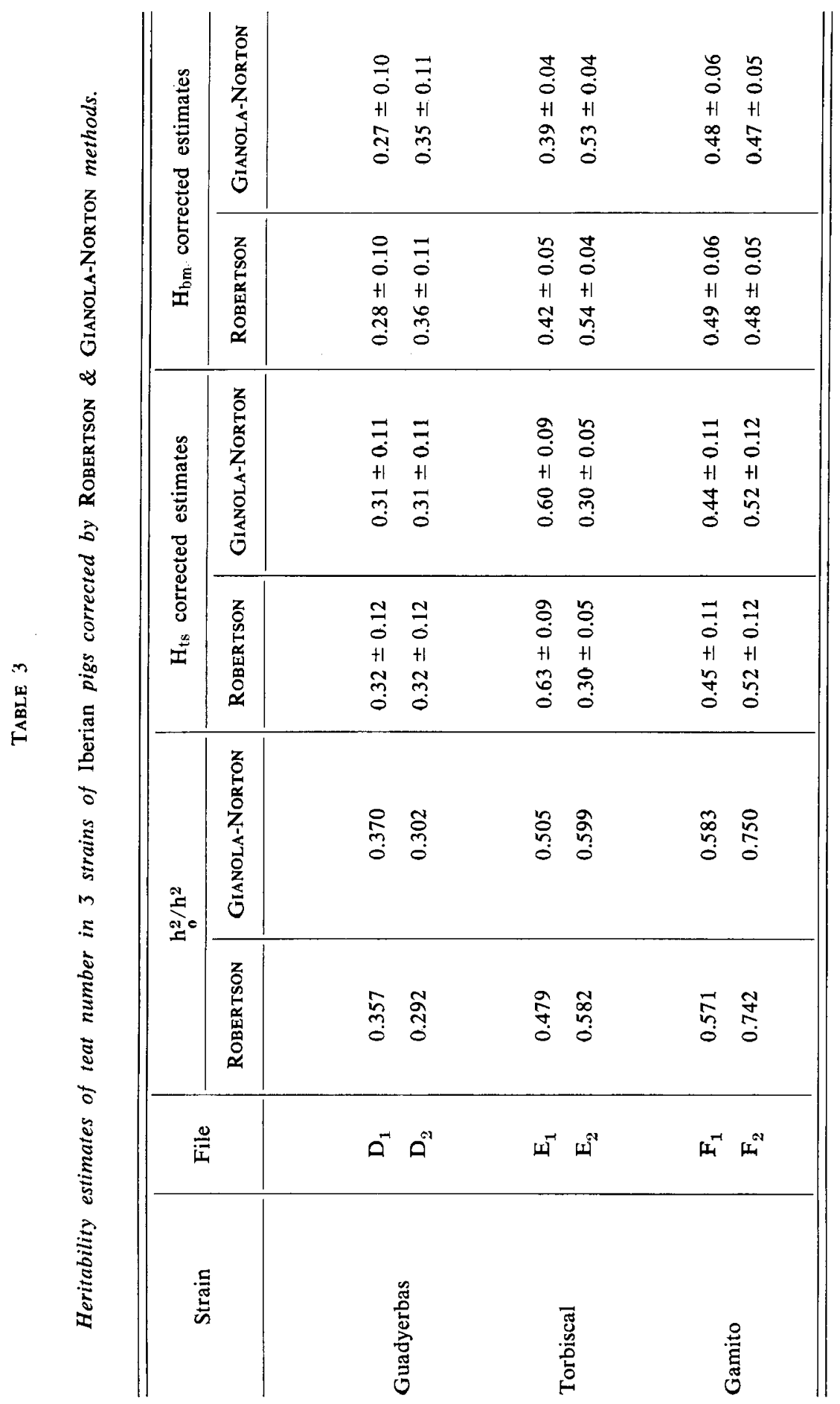




\section{TABLE 4}

Heritability estimates of teat number in 3 strains of Iberian pigs obtained by the TALLIS' method.

\begin{tabular}{|c|c|c|c|c|c|}
\hline \multirow{2}{*}{ Strain } & \multirow{2}{*}{ File } & \multicolumn{2}{|c|}{ Sires/offspring } & \multicolumn{2}{|c|}{ Dams/offspring } \\
\hline & & $h^{2}$ & $\chi^{2}$ & $\mathrm{~h}^{2}$ & $\chi^{2}$ \\
\hline Guadyerbas & $\begin{array}{l}\mathrm{D}_{1} \\
\mathrm{D}_{2}\end{array}$ & $\begin{array}{l}0.18 \pm 0.17 \\
0.48 \pm 0.07\end{array}$ & $\begin{array}{r}14.82 \\
2.98\end{array}$ & $\begin{array}{l}0.62 \pm 0.13 \\
0.05 \pm 0.08\end{array}$ & $\begin{array}{l}4.93 \\
2.54\end{array}$ \\
\hline Torbiscal & $\begin{array}{l}\mathbf{E}_{1} \\
\mathbf{E}_{2}\end{array}$ & $\begin{array}{l}0.39 \pm 0.05 \\
0.24 \pm 0.04\end{array}$ & $\begin{array}{l}39.82 \\
14.56\end{array}$ & $\begin{array}{l}0.34 \pm 0.05 \\
0.48 \pm 0.03\end{array}$ & $\begin{array}{r}2.58 \\
15.60\end{array}$ \\
\hline Gamito & $\begin{array}{l}F_{1} \\
F_{2}\end{array}$ & $\begin{array}{l}0.46 \pm 0.06 \\
0.36 \pm 0.05\end{array}$ & $\begin{array}{r}15.82 \\
3.63 \\
\end{array}$ & $\begin{array}{l}0.52 \pm 0.06 \\
0.69 \pm 0.05\end{array}$ & $\begin{array}{r}13.93 \\
2.97\end{array}$ \\
\hline & & \multicolumn{4}{|c|}{$\chi^{2}{ }_{0.05(8)}=15.51 ; \chi^{2}{ }_{0.01(8)}=20.09$} \\
\hline
\end{tabular}

In view of these results, our opinion of the applicability of these specific methods to estimate the heritability of teat number in pigs may be summarized as follows :

a) in populations where the trait is weakly canalized, the use of conventional methods is acceptable, the value of other approaches, such as that of RoBERTSON, being greater as the degree of canalization increases ;

b) in practical breeding conditions, the use of TALLIS' method is not clearly justified because of the difficulty in strictly fulfilling the assumptions and the complex computations involved.

Received February 2nd, 1985. Accepted October 21, 1985.

\section{References}

Clayton G.A., Powell J.C., Hiley P.C., 1981. Inheritance of teat number and teat inversions in pigs. Anim. Prod., 33, 299-304

DeMPSTER E.R., LeRner I.M., 1950. Heritability of threshold characters. Genetics, 35, 212-235.

Dobao M.T., Rodriganez J., Silio L., Toro M.A., 1982. Sex ratio variation in Iberian pig. II. World Congress on Genetics Applied to Livestock Production, Madrid, 4-8 October, VIII, 537-542.

Dobao M.T., Rodriganez J., Silio L., 1983. Seasonal influence on fecundity and litter performance characteristics in Iberian pigs. Livest. Prod. Sci., 10, 601-610.

Falconer D.S., 1960. Quantitative Genetics, 355 pp., Oliver and Boyd, Edinburgh. 
Foulley J.L., Gianola D., Thompson R., 1983. Prediction of genetic merit from data on binary and quantitative variates with an application to calving difficulty, birth weight and pelvic opening. Génét. Sél. Evol., 15, 401-424.

Gianola D., 1979. Heritability of polychotomous characters. Genetics, 93, 1051-1055.

Gianola D., Foulley J.L., 1983. Sire evaluation for ordered categorical data with a threshold model. Génét. Sél. Evol., 15, 201-224.

Gianola D., Norton H.W., 1981. Scaling threshold characters. Genetics, 99, 357-364.

Hanset R., Camerlynck R., 1974. L'héritabilité du nombre de mamelles chez le porc de Piétrain et le porc Landrace belge. Ann. Génét. Sél. Anim., 6, 91-102.

Harville D.A., MeE R.W., 1984. A mixed-model procedure for analyzing ordered categorical data. Biometrics, 40, 393-408.

KACSER H., BuRNS J.A., 1981. The molecular basis of dominance. Genetics, 97, 639-666.

Legault C., Caritez J.C., 1983. L'expérimentation sur le porc chinois en France. I. Performances de reproduction en race pure et en croisement. Génét. Sél. Evol., 15, 225-240.

Odriozola M., 1976. Investigación sobre los datos acumulados en dos piaras experimentales, 146 pp., Iryda, Madrid.

Pumfrey R.A., Johnson R.K., Cunningham P.J., Zimmerman D.R., 1980. Inheritance of teat number and its relationship to maternal traits in swine. J. Anim. Sci., 50, 1057-1060.

Rendel J.M., 1967. Canalization and gene control, 166 pp., Logos press, London.

SoKal R.R., Rohlf F.J., 1981. Biometry. 2nd ed., 859 pp., Freeman, San Francisco.

TALLIS G.M., 1962 The maximum likelihood estimation of correlation from contingency tables. Biometrics, 18, 343-353.

TURNer H.N., Young S.S.Y., 1969. Quantitative Genetics in Sheep Breeding, 332 pp., Macmillan, Melbourne.

Waddington C.H., 1957. The Strategy of the Genes, 262 pp., George Allen and Unwin, London.

Waddington C.H., 1975. The Evolution of an Evolutionist, 328 pp., Edinburgh University Press.

Zhang W.C., Wu J.S., RemPel W.E., 1983. Some performance characteristics of prolific oreeds of pigs in China. Livest. Prod. Sci., 10, 59-68. 